\title{
PENGARUH ELEMEN-ELEMEN DESAIN KOMUNIKASI VISUAL (DKV) BOX ART GAME TERHADAP STORY LINE BERDASARKAN PERSEPSI GAMERS PADA VIDEO GAME POPULER DI INDONESIA
}

\author{
Muhammad Rizali $^{*}$, Zainal Warhat ${ }^{2 *}$,Edwar Zebua ${ }^{3^{*}}$ \\ Program Studi Kompetensi Penciptaan dan Pengkajian Seni \\ Minat Studi Pengkajian Desain Komunikasi Visual (DKV) Program Pascasarjana \\ Institut Seni Indonesia Padangpanjang \\ Jl. Bahder Johan, Guguak Malintang, Padangpanjang, Kota Padangpanjang, 27126. \\ Sumatera Barat. Indonesia \\ Email: rizalidrawing@gmail.com
}

\begin{abstract}
Abstrak
Tujuan penelitian ini adalah untuk mengetahui pengaruh parsial dan simultan elemen gambar, elemen huruf, dan elemen warna DKV desain Box Art Game pada story line video game. Jenis penelitian ini adalah survey eksplanasi. Instrumen dalam penelitian ini menggunakan kuesioner dengan jumlah sampel sebanyak 151 responden gamer yang diperoleh secara on line melalui media sosial face book. Teknik pengambilan sampel menggunakan acak sederhana dengan cara mengupload kuesioner ke jaringan grup media sosial gamer face book. Teknik analisis data yang digunakan dalam penelitian ini adalah analisis regresi berganda. Instrumen penelitian yang digunakan telah diuji terlebih dahulu validitas dan reliabilitasnya. Persamaan regresi linear dengan menggunaan SPSS diperoleh: $\mathrm{Y}=$ $1,029+0,305 \mathrm{X}_{1}+0,05 \mathrm{X}_{2}+0,250 \mathrm{X}_{3}+$ e. Melalui pengujian hipotesis diperoleh bahwa ada pengaruh parsial elemen gambar $\left(\mathrm{X}_{1}\right)$ dan elemen warna $\left(\mathrm{X}_{3}\right)$ terhadap story line $(\mathrm{Y})$ diterima, sedangkan pengaruh elemen huruf $\left(\mathrm{X}_{2}\right)$ terhadap story line $(\mathrm{Y})$ ditolak. Pengaruh simultan elemen gambar $\left(\mathrm{X}_{1}\right)$, eleman huruf $\left(\mathrm{X}_{2}\right)$ dan elemen warna $\left(\mathrm{X}_{3}\right)$ terhadap story line $(\mathrm{Y})$ diterima. Berdasarkan pengujian hipotesis maka dapat disimpulkan variabel elemen gambar dan elemen warna berpengaruh dalam menjelaskan story line video game. Elemen huruf tidak berpengaruh dalam menjelaskan story line video game. Dalam penelitian ini elemen gambar memberi pengaruh paling besar terhadap story line dengan koefisien regresi 0,305. Secara simultan elemen gambar, eleman huruf dan elemen warna berpengaruh menjelaskan story line video game sebesar $44 \%$.
\end{abstract}

Kata Kunci: desain, box art game, elemen.

\begin{abstract}
The purpose of this study was to determine the effect of partial and simultaneous image elements, letter elements, and color elements DKV design Box Art Game on the video game story line. This type of research is an explanatory survey. The instrument in this study used a questionnaire with a total sample of 151 gamers who were obtained online through face book social media. The sampling technique uses simple random method by uploading questionnaires to the network network of face book gamers. The data analysis technique used in this study is multiple regression analysis. The research instrument used was tested for its validity and reliability. The linear regression equation using SPSS is obtained: $Y=$ $1,029+0,305 X 1+0,05 X 2+0,250 X 3+e$. Through testing the hypothesis, it was found that there was a partial effect of the image element $(X 1)$ and color element $(X 3)$ on the story line $(Y)$ received, while the influence of the letter element $(X 2)$ on story line $(Y)$ was rejected. The effect of simultaneous image elements (X1), letters (X2) and color elements (X3) on story line (Y) is accepted. Based on hypothesis testing, it can be concluded that the variable image elements and color elements are influential in explaining the story line of video games. The letter element has no effect in explaining the story line of video games. In this study the image element gives the most influence on the story line with a regression coefficient of 0.305 . Simultaneously drawing elements, elements of letters and influential color elements explain the video game story line by $44 \%$..
\end{abstract}

Keywords: desain, box art game, elemen.

\section{PENDAHULUAN}

Berdasarkan kebutuhan manusia, desain senantiasa berkembang seiring zaman. Karena pada hakikatnya desain merupakan sarana untuk memecahkan suatu masalah produk. Desain Komunikasi Visual dibuat tidak hanya semata-mata untuk kepentingan sendiri, 
tetapi untuk kepentingan masyarakat banyak yang sesuai dengan keperluannya.. Desain Komunikasi Visual dan Desain Grafis, telah dijabarkan oleh Agus Sachari dan Yan Yan Sunarya (2002:13) sebagi berikut : Desain Grafis kerap disebut sebagai DKV, tetapi organisasi profesi Desain Grafis internasional (ICOGRADA) tetap menggunakan istilah Graphic Design untuk profesi ini, desain yang dibuat ditempatkan pada ilmu-ilmu komunikasi.

Salah satu jenis karya Desin Komunikasi Visual adalah Box Art Game. Box Art Game merupakan salah satu media publikasi yang terdiri atas tulisan, gambar ataupun kombinasi antar keduanya dengan tujuan memberikan informasi kepada khalayak ramai. Box Art Game biasanya di terapkan pada cover disc atau bundle eksklusif bagi pemesan pertama atau biasa di katakan preorder. Story line adalah sketsa gambar yang disusun berurutan sesuai dengan naskah, dengan story line kita dapat menyampaikan ide cerita kita kepada orang lain dengan lebih mudah, karena kita dapat menggiring khayalan seseorang mengikuti gambar-gambar yang tersaji, sehingga menghasilkan persepsi yang sama pada ide cerita kita membedakan genre pada game dan yang terakhir sebagai tanda profesionalisme dari Developer. Pada saat ini banyak di temukan Box Art Game tidak menyinggung isi dari story line pada game dan berakibat game tersebut tidak laku di pasaran. Jika developer sudah mulai melupakan arti dasar dari Box Art Game sebuah game, maka lama kelamaan game yang mereka bikin tidak akan memiliki arti artistik dimata para penikmatnya. Penelitian ini bertujuan untuk mengetahui sejauh mana elemen-elemen DKV mana berpengaruh pada Box Art Game dan membahas kaitannya dengan story line. Hal ini merupakan faktor yang mendorong peneliti untuk mengajukan tema penelitian ini.Secara umum, orang akan lebih cepat menerima pesan dalam bentuk visual dibandingkan dalam bentuk teks. Bentuk visual juga lebih universal ditangkap oleh manusia dengan berbagi latar belakang yang berbeda. Penggunaan desain dalam sebuah karya grafis juga memiliki peran serta manfaat bagi pembaca.

\section{KAJIAN TEORI}

Untuk membahas permasalahan ini maka digunakan berbagai teori, pendapat atau konsep pemikiran yang bersifat teoritis untuk menganalisis desain Box Art Game.

Meurut Jhon C. Beck (2007: 92) Games adalah Game komputer dan Console Platfrom yang dapat dimainkan oleh multipemain melalui internet. Biasanya disediakan sebagai tambahan layanan dari perusahaan penyedia jasa online atau dapat diakses langsung (mengunjungi halaman web yang bersangkutan) atau melalui sistem yang disediakan dari perusahaan yang menyediakan permainan tersebut.

Story line berperan menjadi gambaran dasar dari sebuah produk yang akan kita bangun berikutnya, ini merupakan cetak biru atau algoritma dari apa yang akan kita bangun. Pada awalnya storyboard merupakan kumpulan dari kertas gambar yang berisi rangkaian-rangkaian kejadian dalam sebuah produksi game, termasuk film dan animasi. Selain itu Menurut Dalam tujuan desain merupakan cara berkomunikasi dalam bentuk visual yang menggunakan fasilitas gambar untuk menyampaikan informasi atau pesan seefektif mungkin. Secara umum, orang akan lebih cepat menerima pesan dalam bentuk visual dibandingkan dalam bentuk teks. Bentuk visual juga lebih universal ditangkap oleh manusia dengan berbagi latar belakang yang berbeda. Penggunaan desain dalam sebuah karya grafis juga memiliki peran serta manfaat bagi pembaca. Seperti, mempercepat informasi, memperkenalkan dunia pada masyarakat luas, menggunakan aplikasi yang berbeda-beda dan melihat pesan apa yang ditampilkan. (Widagdo:2000).

Layout merupakan satu keputusan penting yang menentukan efesiensi sebuah operasi dalam jangka panjang. Tata letak memiliki banyak dampak strategis karena tata letak menentukan daya saing perusahaan dalam segi kapasitas, proses, fleksibilitas, daya biaya, kualitas lingkungan kerja, kontak pelanggan, dan citra perusahaan. Tata letak yang efektif dapat membantu organisasi mencapai suatu strategi yang menunjang diferensiasi, biaya rendah, atau respon cepat. Tujuan strategi tata letak adalah untuk membangun tata letak yang ekonomis yang memenuhi kebutuhan persaingan perusahaan (Heizer dan Render : 2009:532). Selain itu Menurut (Hendratman:2015:197) layout adalah usaha untuk menyusun, menata atau memadukan unsurunsur komunikasi grafis, (teks, gambar, tabel dan lainlain) menjadi media komunikasi visual yang komunikatif, estetik dan menarik.

\section{Huruf}

Huruf adalah sebuah grafem (bentuk, goresan, atau lambang) dari suatu sistem tulisan, misalnya 26 huruf dalam alfabet Latin modern, atau 47 huruf dalam Hiragana. Dalam suatu huruf terkandung satu fonem atau lebih (tergantung jenis aksara), dan fonem tersebut membentuk suatu bunyi dari bahasa yang dituturkannya.Menurut (Maharsi:2013:67) banyak yang harus diingat ketika membuat huruf. Baik 


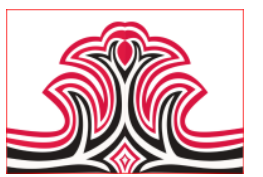

menyangkut bagian - bagian yang terdapat dalam huruf serta panduan - panduan dalam membuatnya.

\section{Warna}

Menurut (Hendratman:2015:79) warna adalah salah satu komponen desain yang membentuk keindahan sekaligus menimbulkan persepsi psikologis, sugesti, suasana tertentu. Meski warna tampak sederhana, namun dibalik itu ada banyak metode/ cara proses pembentukannya.

\section{Gambar}

Gambar merupakan karya yang berasal dari jiwa dan bukan menjiplak milik orang lain. Arief Sadiman, Dkk (2003: 28-29): Media grafis visual sebagimana halnya media yang lain. Media grafis untuk menyalurkan pesan dari sumber ke penerima pesan. Saluran yang dipakai menyangkut indera penglihatan. Pesan yang akan disampikan dituangkan ke dalam simbol-simbol komunikasi visual. Simbol-simbol tersebut perlu dipahami benar artinya agar proses penyampian pesan dapat berhasil dan efisien. Untuk menghasilkan desain yang berkualitas diperlukan berbagai pertimbangan dalam mengorganisasikan elemen-elemen grafis sesuai dengan prinsip-prinsip desain.

\section{Story Line}

Story line adalah sketsa gambar yang disusun berurutan sesuai dengan naskah, dengan storyboard kita dapat menyampaikan ide cerita kita kepada orang lain dengan lebih mudah, karena kita dapat menggiring khayalan seseorang mengikuti gambargambar yang tersaji, sehingga menghasilkan persepsi yang sama pada ide cerita kita.

\section{METODE PENELITIAN}

Jenis penelitian yang digunakan dalam penelitian ini adalah penelitian survey eksplanasi dengan pendekatan kuantitatif. Menurut Sugiyono (2013: 13), metode penelitian kuantitatif dapat diartikan sebagai metode penelitian yang berlandaskan pada filsafat positivisme, digunakan untuk meneliti pada populasi atau sampel tertentu, teknik pengambilan sampel pada umumnya dilakkan secara random, pengumpulan data menggunakan instrumen penelitian, analisis data bersifat kuantitatif/statistik dengan tujuan untuk menguji hipotesis yang telah ditetapkan.

Populasi dalam penelitian ini adalah para anggota aktif Gamers komunitas Facebook Playstation Indonesia yang berinteraksi dengan peneliti dalam sosial media rata-rata 200 anggota dalam sebulan.
Gorga Jurnal Seni Rupa

Volume 08 Nomor 02 Juli-Desember 2019 p-ISSN: 2301-5942 | e-ISSN: 2580-2380

Jumlah sampel yang digunakan dalam penelitian ini minimal sebanyak 133 responden dengan rumus Slovin. Jumlah sampel yang berhasil diperleh selama satu bulan pengumpulan data sebanyak 151 responden.

Objek dalam penelitian ini adalah, Desain Box Art Game yaitu 5 Box Art Game terpopuler di Indonesia meliputi God Of War, Monster Hunter World, Call of Duty World at War II, Assasin's Creed Black Flag dan Grand Theft Auto 5:

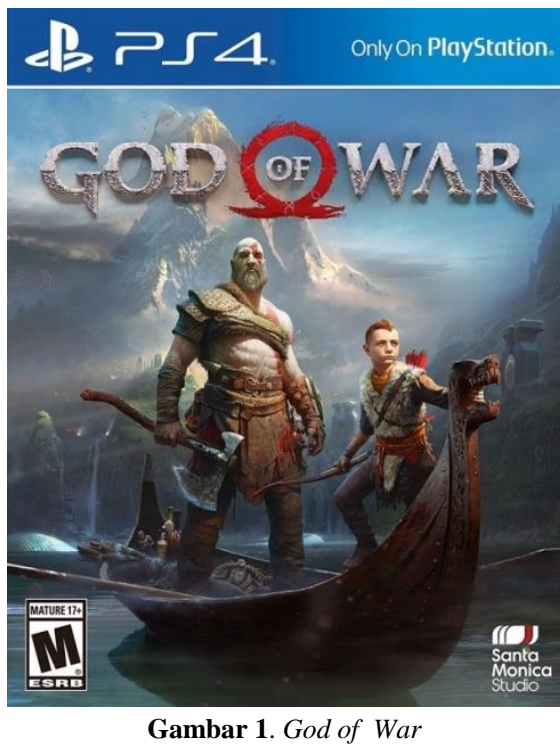

(Sumber: www.playstationstore.com, 2017)

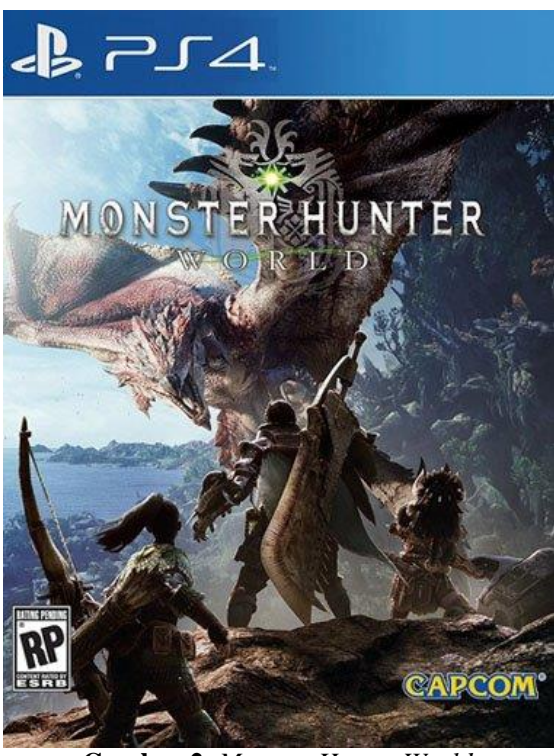

Gambar 2. Monster Hunter World

(Sumber: www.playstationstore.com, 2018) 

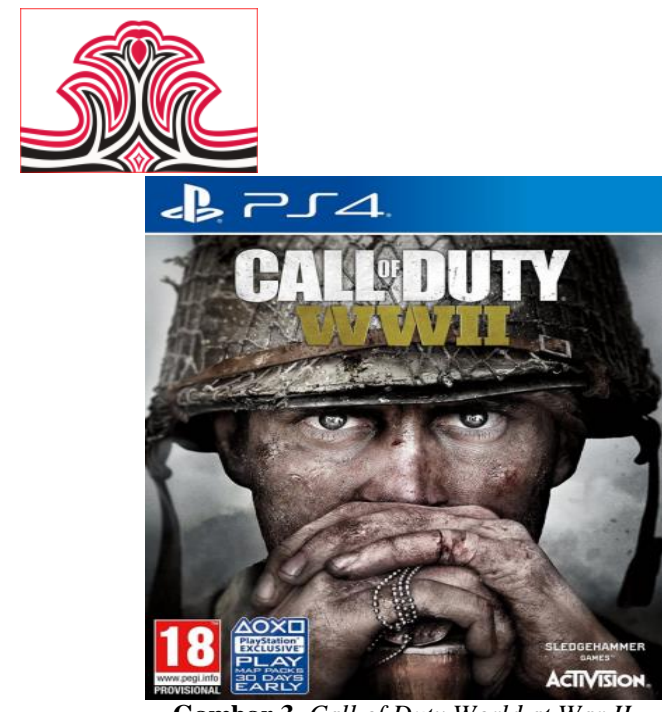

Gambar 3. Call of Duty World at War II

(Sumber: www.playstationstore.com, 2017)
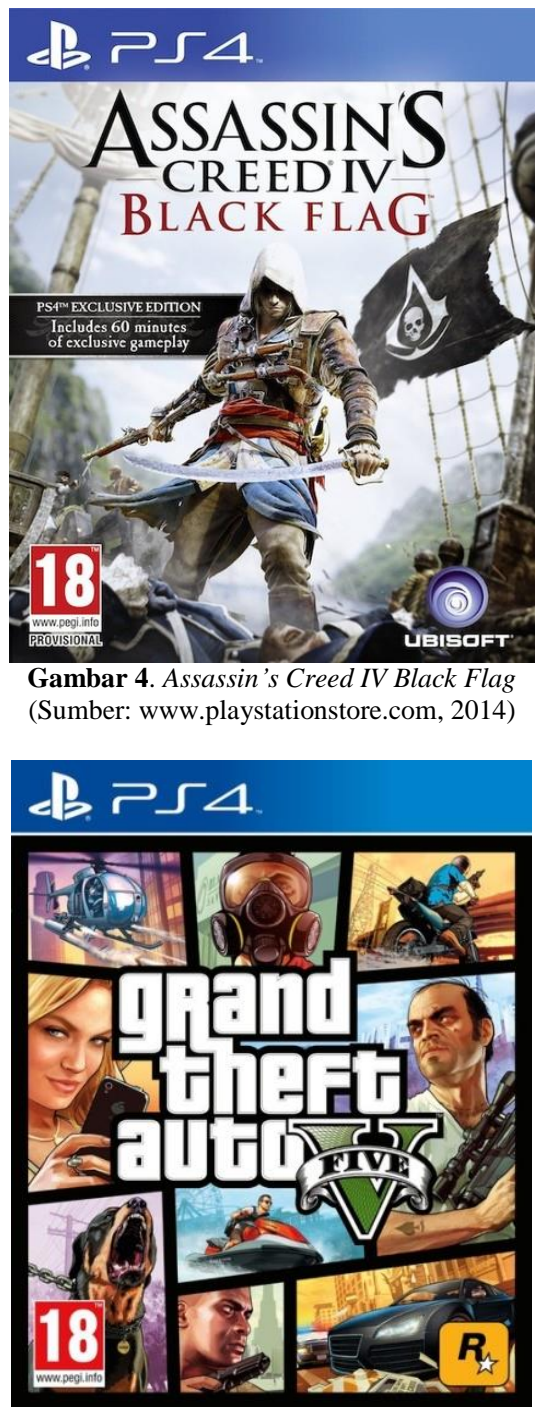

Gambar 5. Grand Theft Auto V

(Sumber: www.playstationstore.com, 2015)

Sedangkan variabel penelitian yang digunakan dalam penelitian ini adalah sebagai berikut :

Variabel Bebas adalah variabel stimulus atau variabel yang mempengaruhi variabel lain (Sarwono, 2008 :107).Variabel bebas dalam penelitian ini adalah elemen-elemen DKV desain Box Art Game yaitu:
Gorga Jurnal Seni Rupa

Volume 08 Nomor 02 Juli-Desember 2019 p-ISSN: 2301-5942 | e-ISSN: 2580-2380

Variabel elemen gambar DKV

Variabel elemen huruf DKV

Variabel elemen warna DKV

Variabel terikat adalah Variabel yang memberikan reaksi / respon jika dihubungkan dengan variabel bebas (Sarwono 2008 : 107 ).

Variabel terikat dalam penelitian ini adalah Variabel Story Line Game: (Y).

Pengumpulan data dalam penelitian ini diperoleh dengan metode kuesioner yaitu berdasarkan jawaban dari para responden atas daftar pertanyaan yang telah di sebar.

Uji validitas digunakan untuk mengetahui sah atau validtidaknya suatu kuesioner.

$$
r_{x y}=\frac{N \Sigma X Y-(\Sigma X)(\Sigma Y)}{\sqrt{\left[N \Sigma X^{2}-(\Sigma X)^{2}\right]\left[N \Sigma Y^{2}-(\Sigma Y)^{2}\right]}}
$$

Dimana :

$r_{x y} \quad$ : Nilai koefosien korelasi

$\mathrm{X} \quad$ : Skor butir

$\mathrm{Y} \quad$ : Skor total

$\mathrm{N}$ : Jumlah responden

$\sum X^{2}$ : Jumlah kuadrat nilai $\mathrm{X}$

$\Sigma Y^{2} \quad$ Jumlah kuadrat nilai $\mathrm{Y}$

Metode analisis yang bersifat menggambarkan keterangan-keterangan dan penjelasan dari hasil koefisien yang diperoleh dan dapat digunakan sebagai pedoman untuk menggambarkan saran. Analisis deskriptif digunakan untuk mendapatkan suatu gambaran mengenai responden dalam penelitian, terutama variabel penelitian yang digunakan.untuk itu akan digunakan program analisis SPSS .

Uji validitas digunakan untuk mengetahui sah atau valid tidaknya suatu kuesioner.

Suatu kuesioner dikatakan reliabel atau handal jika jawaban seseorang terhadap pertanyaan adalah konsisten atau stabil dari waktu ke waktu.

Agar mendapat regresi yang baik harus memenuhi asumsi yang disyaratkan yaitu memenuhi uji asumsi normalitas dan bebas dari Multikolineritas, Heteroskedastisitas, Auto Korelasi, homogenitas dan linearitas. 
Analisis regresi berganda digunakan untuk mengetahui pengaruh elemen-elemen DKV Box Art Game terhadap story line video game. Rumus yang digunakan dalam analisis regresi berganda adalah sebagai berikut:

$$
\mathrm{Y}=\mathrm{a}+\mathrm{b} 1 \mathrm{X} 1+\mathrm{b} 2 \mathrm{X} 2+\mathrm{b} 3 \mathrm{X} 3+\mathrm{e}
$$

Untuk mengetahui ada tidaknya pengaruh variabel bebas terhadap variabel terikat maka dilakukan pengujian terhadap hipotesis yang akan diajukan pada penelitian ini.

\section{HASIL DAN PEMBAHASAN}

\section{Hasil}

Objek dalam penelitian ini adalah, 5 desain box art game dari 5 publisher terkenal diIndonesia yaitu:

Sony Interactive Entertainment,Ubisoft, Capcom, Activision dan Rockstar Games.

Jumlah responden yang mengisi kuesioner secara online dari bulan Mai sampai Juni 2019 sebanyak 151 responden. Jumlah responden ini merupakan sampel dalam penelitian ini.

Tabel 1. Uji Validitas Instrumen Penelitian

\begin{tabular}{|l|l|l|l|l|}
\hline No & Indikator & $\begin{array}{l}\text { Nilai } \\
\text { korelasi }\end{array}$ & $\begin{array}{l}\text { Signifi } \\
\text { kansi }\end{array}$ & $\begin{array}{l}\text { Keterang } \\
\text { an }\end{array}$ \\
\hline 1 & $\begin{array}{l}\text { Background } \\
\text { gambar }\end{array}$ & 0,687 & $<0,05$ & Valid \\
\hline 2 & $\begin{array}{l}\text { Karakter } \\
\text { gambar }\end{array}$ & 0,719 & $<0,05$ & Valid \\
\hline 3 & $\begin{array}{l}\text { Pilihan } \\
\text { huruf }\end{array}$ & 0,647 & $<0,05$ & Valid \\
\hline 4 & $\begin{array}{l}\text { Pilihan } \\
\text { warna }\end{array}$ & 0,726 & $<0,05$ & Valid \\
\hline 5 & $\begin{array}{l}\text { Kecerahan } \\
\text { warna }\end{array}$ & 0,808 & $<0,05$ & Valid \\
\hline 6 & Story line & 0,757 & $<0,05$ & Valid \\
\hline
\end{tabular}

Hasil perhitungan reliabilitas dengan menggunakan uji Cronbach's Alpha dinyatakan sebagai berikut :

Tabel 2. Reliability Statistics

\begin{tabular}{|l|l|}
\hline Cronbach's Alpha & N of Items \\
\hline, 818 & 6 \\
\hline
\end{tabular}

Berdasarkan pada tabel di atas, maka dapat dinyatakan bahwa 6 indikator instrumen penelitian tersebut adalah reliabel karena alpha cronbach's $>\mathrm{r}_{\text {tabel }}$, dimana 0,818 $>0,361$. Penilaian atau persepsi dari 151 responden terhadap variable penelitian disajiakan pada Tabel 3, berikut:
Tabel 3. Skor Variabel-Variabel Penelitian

\begin{tabular}{|l|l|l|l|l|}
\hline \multirow{2}{*}{ Statistik } & \multicolumn{5}{|c|}{ Variabel } \\
\cline { 2 - 5 } & $\begin{array}{l}\text { Elemen } \\
\text { Gambar }\end{array}$ & $\begin{array}{l}\text { Elemen } \\
\text { Huruf }\end{array}$ & $\begin{array}{l}\text { Elemen } \\
\text { Warna }\end{array}$ & $\begin{array}{l}\text { Story } \\
\text { line }\end{array}$ \\
\hline Mean & 4,03 & 3,86 & 3,74 & 3,33 \\
\hline Median & 4,00 & 4,00 & 4,00 & 4,00 \\
\hline Mode & 4,00 & 4,00 & 4,00 & 4,00 \\
\hline $\begin{array}{l}\text { Std. } \\
\text { Deviatio } \\
n\end{array}$ & 1,61 & 0,85 & 1,82 & 1,19 \\
\hline
\end{tabular}

Melalui Tabel 3. di atas dapat dijelaskan hasilnya sebagai berikut.

Untuk variabel elemen gambar. Skor rata-rata (Mean) penilaian responden adalah : 4,03 yaitu dalam kategori tinggi atau baik. Skor yang paling banyak diplih responden atau mode adalah 4 juga dalam kategori baik. Standard deviasi 1,61, artinya rentang skor penilain responden di antara 2,42 s/d 5,64.

- Untuk variabel elemen huruf . Skor rata-rata (Mean) penilaian responden adalah : 3,86 yaitu dalam kategori tinggi atau baik dari empat variabel skor variabell terendah. Skor yang paling banyak diplih responden atau mode adalah 4 juga dalam kategori baik. Standard deviasi 0,85 , artinya rentang skor penilain responden di antara 3,01 s/d 4,71.

- Untuk variabel elemen warna. Skor rata-rata (Mean) penilaian responden adalah : 3,33 yaitu dalam kategori sedang atau cukup. Skor yang paling banyak diplih responden atau mode adalah 4 juga dalam kategori baik. Standard deviasi 1,82, artinya rentang skor penilain responden di antara 1,92 s/d 5,56.

- Untuk variabel story line. Skor rata-rata (Mean) penilaian responden adalah : 4,03 yaitu dalam kategori tinggi atau baik. Skor yang paling banyak diplih responden atau mode adalah 4 juga dalam kategori baik. Standard deviasi 1,61, artinya rentang skor penilain responden di antara 2,14 s/d 4,52

Uji ini untuk melihat bahwa data residu berdistribusi normal, sebagai syarat uji regresi berganda.

Tabel 4. Uji Normalitas Data Residu

\begin{tabular}{|l|l|l|l|l|}
\hline \multirow{2}{*}{$\mathbf{N}$} & Skewness & \multicolumn{1}{|l|}{ Kurtosis } \\
\cline { 2 - 4 } & Statist & Std. & \multicolumn{2}{|c|}{ Std. } \\
Statistic & Error & Statistic & Error \\
\hline
\end{tabular}




\begin{tabular}{|l|l|l|l|l|}
\hline $\begin{array}{l}\text { Unstandard } \\
\text { ized } \\
\text { Residual }\end{array}$ &,- 334 &, 197 &,- 478 &, 392 \\
\hline $\begin{array}{l}\text { Valid N } 151 \\
\text { listwise) }\end{array}$ & & & & \\
\hline
\end{tabular}

Melalui Tabel 4. di atas diperoleh

Rasio skewness $=-0,334 / 0,197=-1,69$

Rasio Kurtosis $=-0,478 / 0,392=-1,21$

Syarat berdistribusi normal jika nilai rasio skewness dan kurtosis diantara -2 s/d 2.

Dengan demikian dapat disimpulkan bahwa data residu persamaan regresi berdistribusi normal.

Uji ini untuk melihat bahwa tidak ada korelasi yang tinggi antara variabel bebas penelitian, sebagai syarat uji regresi berganda.

Tabel 5. Uji Multi Kolinearitas Variabel Penelitian

\begin{tabular}{|l|l|l|l|l|}
\hline \multirow{2}{*}{ Model } & \multicolumn{3}{l|}{ Collinearity Statistics } \\
\cline { 2 - 5 } & B & Tolerance & VIF \\
\hline 1 & Constant) & $-1,029$ & & \\
\cline { 2 - 5 } & Elemen Gambar &, 305 &, 736 & 1,359 \\
\cline { 2 - 5 } & Elemen Huruf &, 005 &, 633 & 1,581 \\
\cline { 2 - 5 } & Elemen Warna &, 250 &, 708 & 1,413 \\
\hline
\end{tabular}

a. Dependent Variable: Story line

Melalui Tabel 5. di atas diperoleh:

Nilai VIF (variance inflation factor) untuk variabel elemen gambar, elemen huruf dan elemen warna seluruhnya $<5$

Dengan demikian dapat disimpulkan bahwa tidak ada masalah multikolinearitas diatanra variabel bebas penelitian.

Uji ini untuk mengetahui bahwa tidak terdapat hubungan antara variabel bebas dengan data residu, sebagai persyaratan analisis uji regresi berganda.

Tabel 6. Uji Heteroskedasitas

\begin{tabular}{|c|c|c|c|c|c|}
\hline \multirow[b]{2}{*}{ Model } & \multicolumn{2}{|c|}{$\begin{array}{l}\text { Koef. } \\
\text { standar }\end{array}$} & k/Koef. & \multirow[b]{2}{*}{$t$} & \multirow[b]{2}{*}{ Sig. } \\
\hline & B & Std. Error & Beta & & \\
\hline \begin{tabular}{|l|l|}
1 & (Constant) \\
\end{tabular} &, 970 &, 225 & & 4,303 &, 000 \\
\hline $\begin{array}{l}\text { Elemen } \\
\text { Gambar }\end{array}$ &,- 016 &, 028 &,- 056 &,- 582 & ,561 \\
\hline \begin{tabular}{|l} 
Elemen \\
Huruf
\end{tabular} &,- 011 &, 057 &,- 020 &,- 190 & 849 \\
\hline $\begin{array}{l}\text { Elemen } \\
\text { Warna }\end{array}$ &,- 006 &, 025 &,- 022 &,- 221 & 825 \\
\hline
\end{tabular}

Gorga Jurnal Seni Rupa

Volume 08 Nomor 02 Juli-Desember 2019 p-ISSN: 2301-5942 | e-ISSN: 2580-2380

Melalui Tabel 6 diperoleh bahwa:

- Signifikansi koefisien regresi variabel elemen gambar, elemen huruf dan elemen warna seluruhnya $>0,05$

- Sehingga dapat disimpulkan tidak ada pegaruh atau hubungan variabel bebas dengan data residu.

-

Tabel 7. Koefisien Regresi Berganda

\begin{tabular}{|c|c|c|c|c|c|}
\hline \multirow[b]{2}{*}{ Model } & \multicolumn{2}{|c|}{$\begin{array}{l}\text { Unstandardized } \\
\text { Coefficients }\end{array}$} & \multirow{2}{*}{$\begin{array}{l}\begin{array}{l}\text { Standardized } \\
\text { Coefficients }\end{array} \\
\text { Beta }\end{array}$} & \multirow[b]{2}{*}{$\mathrm{T}$} & \multirow[b]{2}{*}{ Sig. } \\
\hline & B & $\begin{array}{l}\text { Std. } \\
\text { Error }\end{array}$ & & & \\
\hline \begin{tabular}{|l|l}
1 & (Constant) \\
\end{tabular} & $-1,029$ &, 428 & & $-2,402$ &, 018 \\
\hline $\begin{array}{l}\text { Elemen } \\
\text { Gambar(X1) }\end{array}$ &, 305 &, 053 &, 413 & 5,747 &, 000 \\
\hline \begin{tabular}{|l} 
Elemen \\
Huruf(X2)
\end{tabular} &, 005 & , 108 &, 004 &, 049 &, 961 \\
\hline $\begin{array}{l}\text { Elemen } \\
\text { Warna(X3) }\end{array}$ &, 250 & ,048 &, 382 & 5,209 &, 000 \\
\hline
\end{tabular}

Melalui tabel 7. diperoleh :

- Koefisien regresi elemen gambar $(\mathrm{X} 1)=0,305$ berpengaruh signifikan

- Koefisien regresi elemen huruf $(\mathrm{X} 2)=0,005$, tidak berpengaruh

- Koefisien regresi elemen warna $(X 3)=0,250$

- Konstanta $=-1,029$, berpengaruh signifikan

Sehingga dapat dituliskan persamaan regresi hubungan elemen gambar, elemen huruf dan elemen warna dengan story line pada desain box art video game sbb:

$\mathrm{Y}=-1,029+0,305 \mathrm{X} 1+0,05 \mathrm{X} 2+0,250 \mathrm{X} 3+\mathrm{e}$

$\mathrm{Y}$ : story line.

$\mathrm{X} 1$ : elemen gambar DKV

$\mathrm{X} 2$ : elemen huruf DKV

$\mathrm{X} 3$ : elemen warna DKV.

Tabel 8. Uji Simultan Variabel Penelitian

\begin{tabular}{|l|l|l|l|l|l|l|}
\hline \multirow{2}{*}{ Model } & \multirow{3}{*}{$\begin{array}{l}\text { R } \\
\text { R }\end{array}$} & Square & $\begin{array}{l}\text { Adjusted } \\
\text { R Square }\end{array}$ & $\begin{array}{l}\text { Std. } \\
\text { Error }\end{array}$ & $\begin{array}{l}\text { R Square } \\
\text { Change }\end{array}$ & $\begin{array}{l}\text { Sig. F } \\
\text { Change }\end{array}$ \\
\hline 1 &, $664^{\mathrm{a}}$ & 441 & 430 & 900 &, 441 &, 000 \\
\hline Predictors: (Constant), elemen Warna (X1), elemen & \\
Gambar (X2), elemen Huruf (X3) \\
Dependent Variable: Story line (Y)
\end{tabular}

Melalui Tabel 8. Pengaruh simultan variabel bebas terhadap story line signifikan.

\section{Pembahasan}

Pengaruh parsial variabel elemen gambar (X1) terhadap story line $(\mathrm{Y})$. 
Melalui hasil penelitian diperoleh ada pengaruh elemen gambar terhadap story line dengan nilai positif. Artinya semakin baik kualitas kesesuaian elemen gambar menurut responden maka informasi story line semakin baik dapat diketahui responden.

Dalam penelitian ini besar koefisien regresi elemen gambar terhadap story line sebesar 0,305 , artinya jika kualitas elemen gambar meningkat $1 \%$ maka pemahaman terhadap story line dapat meningkat $0,305 \%$. Pengaruh elemen gambar terhadap story line paling besar dibandingkan pengaruh elemen huruf dan elemen warna.

Pengaruh parsial variabel elemen huruf (X2) terhadap story line (Y).

Melalui hasil penelitian diperoleh tidak ada pengaruh elemen huruf terhadap story line. Artinya dalam penelitian elemen huruf tidak berperan dalam menjelaskan story line.

Dalam penelitian ini besar koefisien regresi elemen huruf terhadap story line hanya sebesar 0,05 atau telalu kecil. Sehingga pengaruhnya tidak berati.

Pengaruh parsial variabel elemen warna(X3) terhadap story line (Y).

Melalui hasil penelitian diperoleh ada pengaruh elemen warna terhadap story line dengan nilai positif. Artinya semakin baik kualitas kesesuaian elemen warna menurut responden maka story line semkin baik dapat diketahui responden.

Dalam penelitian ini besar koefisien regresi elemen gambar terhadap story line sebesar 0,250, artinya jika kualitas elemen warna meningkat $1 \%$ maka pemahaman terhadap story line dapat meningkat $0,250 \%$.

Pengaruh simultan variabel elemen gambar(X1), huruf (X2) dan warna(X3) DKV terhadap story line $(\mathrm{Y})$.

Melalui hasil penelitian diperoleh ada pengaruh simultan elemen warna, huruf dan gambar terhadap story line dengan nilai positif. Artinya semakin baik kualitas kesesuaian elemen warna, huruf dan gambar menurut responden maka story line semkin baik dapat diketahui responden.

Dalam penelitian ini besar koefisien korelasi determinasi $\mathrm{R}$ sebesar 0,664 terhadap story line atau dengan besar pengaruh $44 \%$ terhadap sory line. Artinya elemen gambar, elemen huruf dan elemen warna DKV dapat berperan $44 \%$ dalam menjelaskan story line video game. Sisanya $56 \%$ dijelaskan oleh variabel lain yang tidak dianalisis dalam penelitian ini.

\section{KESIMPULA DAN SARAN}

\section{Kesimpulan}

Melalui hasil Penelitian dan pembahasan maka dapat ditarik kesimpulan sebagai beikut:

Ada pengaruh parsial elemen gambar DKV desain Box Art Game pada story line video game dengan koefisien regresi 0,305. Dalam penelitian pengaruh elemen gambar DKV terhadap story line video game paling besar dibandingkan variabel lain. Penilaian elemen gambar DKV desain box art game oleh responden dengan nilai rata-rata 4,06 atau dalam kategori baik.

Pengaruh parsial elemen huruf DKV desain Box Art Game pada story line video game dengan koefisien regresi 0,05. Dalam penelitian pengaruh elemen uruf DKV terhadap story line video game sangat kecil atau tidak berarti. Artinya elemen huruf tidak berperan dalam menjelaskan story line video game.

Ada pengaruh parsial elemen warna DKV desain Box Art Game pada story line video game dengan koefisien regresi 0,250 . Dalam penelitian pengaruh elemen warna DKV terhadapa story line video game lebih rendah dibandingkan elemen gambar DKV. Penilaian elemen warna DKV desain box art game oleh responden dengan nilai rata-rata 4,74 atau dalam kategori baik.

Ada pengaruh simultan elemen gambar, elelemen huruf dan elemen gambar DKV desain Box Art Game pada story line video game dengan koefisien korelasi $\mathrm{R}=0,664$ dan besar penagruh $44 \%$. Artinya elemen gambar, elemen huruf dan elemen warna DKV dapat berperan $44 \%$ dalam menjelaskan story line video game. Sisanya $56 \%$ dijelaskan oleh variabel lain yang tidak dianalisis dalam penelitian ini.

\section{Saran}

Bagi Publisher video game dalam mengembangkan desian box art game. Variabel utama DKV yang harus diperhatikan dalam mendesain box art game jika dikaitkan dengan sory lain adalah elemen gambar dan elemen warna sedangkan elemen huruf kurang berperan.

Bagi peneliti lanjut dapat mengembangkan penelitian dengan mencari variabel lain yang berperan dalam menentukan story line video game. Dalam penelitian ini elemen gambar, elemen huruf dan elemen warna baru dapat berperan menjelaskan $44 \%$ tentang story line video game. Masih ada $56 \%$ peran variabel lain dalam menjelaskan story line video game. 
DAFTAR RUJUKAN

Agus Sachari, Yan Yan Sunarya. (2002). Sejarah Dan Perkembangan Desain Dan Dunia Kesenirupaan Di Indonesia. Bandung: Institut Teknologi Bandung.

Arief S. Sadiman, dkk. (2012). Media Pendidikan: Pengertian, Pengembangan dan Pemanfaatannya. Jakarta: PT. Raja Grafindo Persada

Beck, John C dan Mitchell Wade. (2007). Gamer Juga Bisa Sukses. Jakarta : PT Grasindo.

Heizer, Jay dan Barry Render. (2009). Manajemen Operasi Buku 1 Edisi 9. Jakarta: Salemba Empat.

Hendratman Hendi. (2015). Computer Graphic Design. Hal. 79 Warna. Bandung : Informatika

Hendratman Hendi. (2015). Computer Graphic Design. Hal. 197 Tata Letak Layout.Bandung : Informatika.

Sugiyono. (2013). Metodelogi Penelitian Kuantitatif, Kualitatif Dan R\&D. Bandung: ALFABETA.

Widagdo. (2000). Desain dan Kebudayaan. Bandung : Penerbit ITB.

www.playstationstore.com 